\title{
"Jerome at the BBC": Subversion, caricature, and humanity in Three Men in a Boat
}

\author{
Dalbir S. Sehmby \\ Campus Saint-Jean, University of Alberta, Canada
}

\begin{abstract}
Through characters who openly express distress over imagined pains, "Jerome at the BBC" treats $B B C$ 's Three Men in a Boat as a playful critique of heroic masculinity, or what the paper defines as confident cognisant agency. Airing in 1975, BBC's adaptation is released after the media ascension of James Bond and in the heyday of tough Hollywood heroes, bold figures who refuse to complain about, let alone give in, to physical pain - unlike Jerome's men. Jerome's original and its BBC adaptation are layered comical texts. By channelling Jerome's critique of the colonial, seafaring male into contemporary notions of the Hollywood-hero type, this paper examines the BBC film's boisterous lack of masculine agency, the quiet parody of action sequences, and the gingerly movement towards a conclusion that does not bang, but whimpers. Moreover, the paper asserts that the humour also functions on a less grand level, by being an effective caricature of human behaviour - a healthy dose of cultural self-mockery. Furthermore, through revealing moments, by the telefilm's end, the characters do not simply remain caricatures to be laughed at, but become identifiable and relatable human beings.
\end{abstract}

Keywords: Three Men in a Boat; Jerome K. Jerome; BBC; Tom Stopard; Tim Curry; Michael Palin; Stephen Moore; Robinson Crusoe; Sherlock Holmes; James Bond 


\section{Introduction: Three Men, three layers}

"You grow up the day you have your first real laugh... at yourself".

Anonymous

The opening folk saying applies to Jerome K. Jerome's Three Men in a Boat (To Say Nothing of the Dog) because of the underlying comic pivot, one that critiques the late nineteenth century imperialist image of the rational, capable, and superior British male - the conqueror of the seas and colonies. Disguised behind the thin veil of its own legend of being accidentally humorous, Jerome's Three Men is a comical cultural self-portrait, a mature artistic moment of laughing at the imperial and patriarchal hubris that inspires the dangerously humourless belief in hypermasculine leadership and heroics. Three Men reveals the bias of patriarchal self-image that reaches across the empire, an image that is built not only by colonial enterprise, but also by literary celebrations of the enterprising seafarer. More than just a comical subversion of European seafaring masculinity, the literary and cinematic life of Three Men hints at its ongoing cultural appeal, speaking to any place where a patriarchal culture posits masculinity as the primary excuse for social and political dominance - and to those mature enough to laugh at such an excuse. Adapting Jerome K. Jerome's original in 1975, BBC delivers a combination of notable talents via the direction of Stephen Frears, the teleplay by Tom Stoppard, and the star power of Tim Curry, Michael Palin, Stephen Moore... and a dog. While Jerome's initial version is recognised as a classic sample of British humour and a playful critique of Victorian character, the 1975 BBC version can also be seen as an anti-action film through which the tradition of heroic cinematic masculinity is subverted. Jerome's Three Men can be positioned as a (deliberate or accidental) comic response to literary figures like Crusoe and other adventurers who have become reinforcements for the idea of both racial and gender superiority within the imperial context. Adapting Jerome's original text into a BBC telefilm re-contextualises the original parody, positioning it as a comical variation to cinematic representations of heroic masculinity; as a result of its temporal context, the $\mathrm{BBC}$ version ends up comically reflecting upon the masculinity depicted by a lineage of capable and uncomplaining male hero types in cinema. Ultimately, however, BBC's Three Men works on three interweaving levels: one of heroic subversion, another one of observational humour and caricature (of Victorian life), and a third one of relatable human characterization.

Before exploring heroic subversion, it is important to address three elements: one, the status of the original as coincidently humorous; two, the extension of William Scheick's (2007) interpretation of Jerome's original; three, the definition of confident cognisant agency.

\section{Qualifying Jerome's humour}

In terms of the infamous status of the original, Jerome directly states that he "did not intend to write a funny book at first" (Jerome 1982: 9), thereby fuelling the longstanding legend surrounding the comical innocence of Three Men in a Boat. With such a statement, Jerome emphasises not only the function of happenstance during the inception process, but also assumes that the instant success of his work was due to its "natural" humour. However, many works are 
humorous without selling millions worldwide or enjoying over a century of publication. Jerome's follow-up in 1900, Three Men on the Bummel experienced some success, but it has not endured as well as the original adventures. Although the comparable quality of the work may be a factor (as occurs in the diminishing returns of three men sequels, as with the Hangover movies), the indirect claim (and emphasis) here is that, ideologically, the story about three men on a boat taps into the British cultural psyche. It is also important to note that the "Three Men" concept is not entirely original. Before Three Men, from 1882, there is Three in Norway, by J. A. Lees and W. J. Clutterbuck, which has endured, but without the same force as Three Men in a Boat.

With this in mind, Jerome's statement about the unintentional origins of a humorous classic requires some commentary. Firstly, Jerome's claim is understandable. Since humour depends on surprise, Jerome's positioning of the reader into one who is engaging with a text that is only accidently humorous actually helps the text. The text alleviates the potential pressure on itself and appropriately so, for its humour is not as outrageous (and thus as obvious) as, for instance, Voltaire's Candide, or in cinema, the Austin Powers series or Ace Ventura series. While the reputation of being accidentally humorous helps the text, this legend downplays the text's design. Secondly, the existence of Three in Norway hints at a direct predecessor and possible model to Jerome's work, while Jerome's previous works - On the Stage and Off: The Brief Career of a Would-Be Actor (1885) and Idle Thoughts of an Idle Fellow (1886) - are proof of Jerome's artistic inclination towards humour. These two facts lend less credence to Jerome's claim that he aimed to be more serious than he was. At least, critical emphases on Three Men in a Boat as accidentally humorous require some serious re-evaluation. Thirdly, Jerome's claim against the text's humour may help hide its parody of masculinity and its potentially more satirical ideological critique of male agency championed by popular literary depictions of British masculinity of the time. Within the late nineteenth century literary context of daring adventures from Sir Arthur Conan Doyle, Robert Louis Stevenson, and Rudyard Kipling, the exploits of George, Harris, and Jerome function as a parody of the capable, resilient, uncomplaining, actionoriented British male character type. Since late nineteenth century literary style has gone out of favour, there may be a limit to the enduring popularity of Jerome's original. Parody works, in part, due to the knowledge of the works and styles being parodied. Jerome's literary style is arguably heavy and slow, compared to the flashier, in-your-face parody of more contemporary humour, such as The Simpsons or South Park. Nevertheless, from three men walking into a bar to ensemble comedy films (Hangover), the concept of a group of inept males on a quest of some sort remains a viable comic staple.

In other words, the legacy of Jerome's positioning of Three Men in a Boat as unintentionally humorous may have caused scholars to overlook Three Men in a Boat's potential as a satiric jab at the ideal, British colonial male. Moreover, dismissing Three Men in a Boat's humour as coincidental overlooks the comic artistry of the work, the multiple comic layers layers that this paper will explore later.

\section{Extending Scheick's Theory of Imperial Link}

Jerome's Three Men in a Boat and BBC's Three Men in a Boat can be understood as texts that comically undercut the literary, cinematic, and broadcast media tradition of representing heroic males. Challenging the traditional hero story setting, Jerome alters the exotic locales of adventure 
narratives typical for colonial/patriarchal hero adventure narratives by presenting a local English setting. Referring to Henry M. Stanley's search for Livingstone down the Nile, Jerome's Three Men alludes quite directly with "they're a-going to find Stanley" (Jerome 1982: 50). In "Going to Find Stanley", William J. Scheick addresses this Imperial link; in particular, Scheick treats Jerome's most famous work as a conceptual parody of Stanley and Livingstone's search for the source of the Nile. Scheick (2007: 407) points out how certain Imperial narratives are the possible source for Jerome's comical treatment: “Jerome's satiric Nile-like upriver adventure narrative set in a foreign-seeming, sometimes barbaric England amounted to only a broad and irreverent application of the imperial narrative model, but it nonetheless sold as spectacularly as How I Found Livingstone and King Solomon's Mines". Altering the location from Africa to England, and moving away from the exotic mystery and adventure associated with the Nile to the routine of leisure trips on the Thames point out an effective comic reversal. The heroic weightiness of and exotic mystery associated with Stanley's dangerous search is re-contextualised into the actions of three self-diagnosed "invalids" taking a leisurely, local boating trip.

The following analysis agrees with Scheick, but extends Jerome's men on a boat comic imagery further back, and thus treats Jerome's men as comical variations of the capable heroic male embodied by Robinson Crusoe and Odysseus. Rather than treating Jerome's source text as it is frequently emphasised, as accidentally (and thus innocently) humorous, this analysis positions the humour in Jerome's Three Men in a Boat as an anti-thesis to conceptualizations of the heroic male (in general) and, especially, of the colonial British ideal, the enterprising seafarer. In doing so, this analysis characterises masculine heroics through the quality of confident cognisant agency - a quality that persists into more contemporary cinematic heroes.

\section{Defining confident cognisant agency}

It is difficult - if not impossible - to characterise the traits of major male heroes, as each hero in each work offers some important variations to one another. Nevertheless, as a potential aid in understanding Jerome's Three Men in a Boat as a comic counterpart to narratives of heroic masculinity, it is helpful to provide a general characterization of heroic masculinity via the notion of confident cognisant agency. Confident cognisant agency refers to a merger of traits typified by mainstream (literary or cinematic) masculine heroes, with confidence being their steady nerves during times of stress, cognizance being their ability to solve problems (like Odysseus and Sherlock Homes) and exhibit survival skills in the most difficult situations (like Robinson Crusoe or James Bond), and agency being their ability to affect the narrative world. Confident cognisant agency is a characteristic that can be found in the non-fictional heroics of Stanley, as well as the fictional cinematic heroics of rugged and capable 1970s male heroes, such as Clint Eastwood. Therefore, by extension, the 1975 BBC telefilm is not only an adaptation of Jerome's text, but it also comically portrays the heroic masculinity of 1970 s popular culture.

Whether fictional and/or non-fictional, by earnest effort and/or performed persona, heroic figures are considered valuable members of society or characters in literature because they are perceived to embody confident cognisant agency, an ability to successfully wield body and mind. In Manliness, Harvey C. Mansfield identifies an association between confidence and prowess. Focusing particularly upon manly virtue, Mansfield (2006: 23) claims manliness is "confidence in the face of risk". Building upon ancient Greek philosophical notions (especially from Plato and 
Aristotle) of manly virtue, Mansfield builds a case for the positive value of manliness, claiming that manliness is a virtue embodied only by a few men and women. Reviving the concept of thumos and andreia, Mansfield (2006: 221) believes that "assertiveness in the face of risk is a task of political responsibility". Manliness defends people from tyrants, exhibits a preference for action over reflection, and "asks us to continually prove ourselves" (ibid.: 20). In a variety of non-fictional and fictional examples, heroic males demonstrate intelligence, prowess, and success. In fiction especially, confidence marks the determined swagger of masculine heroes. More than elements of brute force, heroic figures have a special cognizance, for they display high degrees of knowledge and skill; at times, their cognitive abilities seem even supernatural. Perhaps most importantly, heroes exhibit agency, for they are beings of successful action - so much so that they have epic poems written about them.

In terms of leading up to Jerome's comic critique of heroic masculinity, it is important to review a sample of precursors, beginning with ancient Greek literary figures. For instance, Achilles and Odysseus exhibit confident cognisant agency. Confidence, or the belief in one's own abilities, is apparent in both Achilles and Odysseus. In terms of cognizance, Achilles displays superhuman skills as a warrior, while Odysseus is known for his cunning intellect. As for agency, while Achilles effectively slays his chief rival, Hector, Odysseus eventually finds his way home. Notably, as it relates to the Imperialist image, in ancient Greek myth, the idea of being civilised is associated with a seafarer, Odysseus, who must find his way home, to his kingdom. By the beginning of the Odyssey, there is a clear division between the often savage world of his adventures and that of Odysseus' desired destination, his civilised kingdom; moreover, there is a distinction - although at times tenuous - between Odysseus and other characters, with Odysseus being lauded as a capable leader. The implication is that Odysseus is the more intelligent and civilised than the many beings he encounters. For instance, in the early episode with the Cyclopes, the distinction between the savage and Odysseus is perhaps at its clearest. Another example of Odysseus' civility is when, rather than giving into base temptation, Odysseus's restraint saves him from the sirens. With Circe's witchcraft and sexuality, the distinction between uncivilised and civilised becomes less clear; regardless, even though some men can turn into pigs, Odysseus does successfully return home to his faithful wife. In disguise to test the faithfulness of his wife and thwart suitors through the stringing of the bow and his archery skill, Odysseus succeeds in taking his position at the peak of civilised society, as king. Moreover, the climactic episode of the Odyssey further highlights the confident cognisant agency of Odysseus. The three elements of seafaring, a heroic male, and a contrast between the civilised and uncivilised hold a special importance as literary precursors to the British literary imaginings of colonial masculinity.

In terms of folkloric British literary examples of heroic masculinity, it is important to mention Beowulf, where the boundaries between the more civilised, titular hero and the savage monster, in the form of a flesh-eating Grendel, configure the basis of the central conflict. Despite the potential parallels between Beowulf and Grendel, as with Odysseus and the Cyclopes, the consumption of human flesh separates the civilised from the uncivilised. Hence, there is a line drawn that separates and thus associates a particular type of masculinity, Beowulf's, as acceptable. Like Odysseus, Beowulf is royalty. The status of the two heroes is determined by an assumed hierarchical and binary divide, of their royalty and more civilised ways, which are contrasted to the monstrous and uncivilised manners of their enemies - outsiders to their kingdom. Importantly, early in Beowulf, great warriors board a ship, and before any monster can 
be slain, they must overcome churning waves. Like Odysseus, then, apart from his traditional heroic background, or physical and mental prowess, Beowulf has the ability to conquer dangerous waters and this ability helps found the British myth of seafaring masculinity.

In at least two well-respected and foundational literary texts, there are a few key recurring elements: a royal, seafaring hero who exists as a civilised contrast to his encounters with the savage or monstrous. While there is a recurring contrast between the savage and the civilised seafaring hero in the English canon, the enterprising colonial male in search of adventure and fortune is more directly evident in Robinson Crusoe. Like Odysseus, Robinson Crusoe exhibits confident cognisant agency because he is able to survive and maintain his civility in a savage place. Moreover, with Crusoe, the particular myth of seafaring masculinity embraced by the colonial imagination becomes more apparent. By putting aside Jerome's claim about the unintentional humour, extending Scheick's theory, and establishing confident cognisant agency, the analysis can move into the text's subversion of heroic masculinity, beginning with the image of the British seafarer.

\section{The British myth of the seafarer: Robinson Crusoe}

Jerome's Three Men in a Boat taps into intrinsic cultural material, a notion of masculinity that helps define British character: the seafarer. If America has the frontier, then England has the sea. The sea functions as a dangerously powerful force of nature, upon which seafarers attempt to display their confident cognisant agency. In the early eighteenth century, Robinson Crusoe emerges as a literary icon of highly capable British masculinity. Coupled with actual colonial expansion, Crusoe's emblematic masculinity correlates with the increasing eighteenth century interest in racial pseudo-science. The assumption was that "the human races were separated from each other by such profound mental, moral and physical differences as to constitute separate biological species of humankind" (Stepan 1982: 2). This is, of course, not to say that the entire British population believed in their superiority to other races, but Crusoe, even though a fictional figure, fed into circulating notions of white male capability and cultural superiority.

While seafaring narratives predate Crusoe, and even though variations of the island castaway exist to this day, Robinson Crusoe remains a significant locator of heroic masculinity. In The Sailor in English Fiction and Drama: 1550-1800, Watson illustrates how voyage narratives and dramas have been a consistent part of English literature during the rise of British Imperialism, leading Watson (1966: 3) to comment "the sailor has practically always been an important character". Hence, a certain mystique was being built around the seafaring hero. Even though seafaring no longer has the central hold over the public's imagination as it once did, variations of the inventive and resourceful Robinson Crusoe linger into the twentieth and twentyfirst century, with figures like television's MacGyver, the Hollywood film Castaway, and even the popular television series, Survivor. Inspired in part by the age of British seafaring, the voyages of Star Trek's U.S.S. Enterprise continue into the new millennium. In other words, Daniel Defoe's Robinson Crusoe exists as a landmark colonial novel that, since its publication in 1719 , has been resonating throughout popular culture.

Significantly, unlike Odysseus or Beowulf, Crusoe is neither king nor prince. Rather, Crusoe dares to escape mediocrity with Crusoe's father providing the following inspiration: 
He told me it was men of desperate fortunes on one hand, or of aspiring, superior fortunes on the other, who went abroad upon adventures, to rise by enterprise, and make themselves famous in undertakings of a nature out of the common road; that these things were all either too far above me or too far below me; that mine was the middle state, or what might be called the upper station of low life, which he had found, by long experience, was the best state in the world, the most suited to human happiness, not exposed to the miseries and hardships, the labour and sufferings of the mechanic part of mankind, and not embarrassed with the pride, luxury, ambition, and envy of the upper part of mankind. (Defoe 1975: 5-6)

Rather than being satisfied with "the upper station of low life", being the individualist he is, Crusoe rebels. In "Robinson Crusoe and the Ethnic Sidekick", Frederick Zackel (2000) considers Crusoe as a new type of self-defined hero, because of the use of first-person narration. Unlike the ancient Greek epics, where Homer is the source and a muse serves as divine inspiration, Robinson Crusoe is, in a sense, his own maker. He is the narrative authority of his adventures, establishing his own Eden, rather than simply attempting to re-enter the Eden he left behind. Crusoe is the supposed author of the text, not Defoe; indeed, the text mimics the style of nonfictional journal entries. As a result, this confusion between imagined author and his creation helps make Crusoe more of an imagined ideal of the enterprising seafarer, differently from the mythic Odysseus before him or the non-fictional Stanley after him. As a testimonial to the possible reception of the novel as non-fictional, it is significant to cite Rogers (1979: 5), who claims that "Defoe's name did not appear" on the early editions. Crusoe becomes a cultural force in his own right, not simply as another fictional creation, but as an ideal type of man: the intelligent, risk-taking, inventive, and capable adventurer. The non-fictional link of Crusoe to Alexander Selkirk amplifies the emergence of the self-reliant, heroic seafarer. Crusoe is valued for his resourcefulness and ingenuity, and these values become especially significant in the burgeoning capitalist system, where new ideas or new spins on old ideas promise profit.

Demonstrating Robinson Crusoe's vast appeal and huge multi-national success, in "Robinson Crusoe", Zackel (2000) says: "Robinson Crusoe was an immensely popular story to the European colonial mentality. It went to four editions within the first four months, spawned two mediocre sequels, and then went on to be published in over 700 editions throughout Europe and America within a century. The novel has never been out of print". Crusoe's status as a lone figure cannot be overstated; although indirectly working for the ideal of an enterprising spirit, he is rather alone, and, in that regard, he is working by and for himself. Published a century after the founding of the Dutch East India Company and well over a century before Stanley's How I Found Livingstone (1872) or Through the Dark Continent (1890) and Haggard's King Solomon's Mines (1885), Crusoe marks a meeting point of literary adventure fiction with the non-fiction of seafaring exploration; in the process, Robinson Crusoe becomes an important point in popular conceptions of masculinity.

In the history of literature, it is important to note briefly that Robinson Crusoe is complemented by other accounts of exotic travel, especially those that take the stance of objective observation. Of particular relevance to the style of Jerome, there are privateer narratives, which embody an objective style by communicating different locales: "Basically, the formula may be described as chronological in movement from place to place, topical in describing the particulars of each place. Much geographical detail is given about the places and 
about the natives and their customs" (Hunter 1966: 15). Such works draw attention away from character and focus on the areas being explored. First-person narration and a leisurely exploration of locale also characterise Jerome's Three Men in a Boat, albeit with a deliberately more comical aim.

\section{BBC's anti-action film}

By the time of Jerome, there are, thus, several models of general mythic masculinity (Odysseus, Beowulf), of the more specific British seafarer (Crusoe), and of the rugged adventurer (Stanley), swirling around the public's imagination. To this, one could add the objective tone of travel narratives. Together, such literature helps forge cultural boundaries, a sense of community reinforced by the values communicated via protagonists like Crusoe. While Imperialist explorers had the status of civilised, objective, and authoritative observers of foreign cultures, Jerome's Three Men reverses the lens of the British explorer to Britain itself. In the style of privateer travelogues, Three Men provides educational commentary of the locales visited along the voyage. Like the comic travelogues of Candide's Voltaire and Swift's Gulliver's Travels, but much less grandiose and much more rooted in realism, Three Men engages in a comical self-anthropology. If Jerome's original is a potential comic counterpoint to seafaring narratives and heroes, then the 1975 BBC film version (intentionally or unintentionally) serves a similar function for cinematic depictions of confident cognisant agency.

By the time the BBC adapted Jerome's most famous work for television, there had already been several film versions with Challis Sanderson's in 1920, Graham Cutts' in 1933, and Ken Annakin's in 1956. Compared to the original novel, with its rather nuanced cultural references to early nineteenth century life, BBC's 1975 adaptation is delivered with broader strokes, while maintaining a realistic tone. To elaborate, unlike Gulliver's Travels which veers into fantastic situations, and thus lends itself to cinematic adaptations that emphasise the extraordinary, Jerome's original and the BBC adaptation sustain a relatively grounded, realistic tone. As a result, unlike the obvious parody of Gulliver's Travels or Pink Panther, the art of Jerome's and BBC's Three Men in a Boat exists in their understated critique of masculine competence. By taking on the voice of the objective observer, like Crusoe, Jerome's self-made man is not very well made; there is a dissonance between the authoritative narrative voice and the visual sequences which exhibit a lack of his authority or power.

By 1975, mainstream media had invested in several variations of the masculine hero's exhibitions of confident cognisant agency, both non-fictional and fictional. Alongside cinematic representations of heroism though, there is also a long-standing comic tradition of subverting the male hero, into which BBC's Three Men in a Boat fits rather nicely. In popular culture, the confident cognisant agency of the male hero was not the only masculinity on display, for as early as silent cinema, Chaplin and Keaton, amongst others, present a masculinity that undermines the heroic, and thus serve as a comic counterbalance to the popular hero. By the time sound cinema emerges, there is a need to move away from visual action and towards dialogue, a need that is fulfilled in part by the rise of the screwball comedy. Jerome's original, due to its witty commentary and dialogue, suits this need appropriately and makes for a smooth transition into the selective choices of the BBC adaptation. The use of three central figures resembles the film tradition of comedy teams or ensemble troupes, especially of a group like the Three Stooges or 
the Marx Brothers. Being bachelors, Jerome's three men also fit into the bachelor comedy team subgenre that is still around with Three Men and a Baby, Three Amigos!, and The Hangover series. Therefore, in terms of characterisation and visuals, BBC's Three Men follows in the heroic subversion tradition with its use of visual gags and slapstick, while, in terms of sound, BBC's Three Men works well as a verbal (as in screwball) comedy, both because of its selective use of voice-over and its reliance on witty dialogue. Being a selective adaptation of Jerome's original, BBC's Three Men makes certain visual and aural comic choices that associate BBC's Three Men with particular comic genre traditions.

The timing of Jerome's piece during the glory of the British Raj positions Jerome's incapable men in contrast to the heroic ideal championed by colonial politics and propaganda. Unlike the Englishmen who can brave the midday sun, Jerome, George, and Harris cannot seem to handle their sheltered, comfortable lives. And thus, due to its place in history, Jerome's Three Men comically comments (consciously or unconsciously) on the heroic ideal of its time. Similarly, BBC's Three Men in a Boat appears at a significant time in the history of cinema and gender politics. In 1975, with the postcolonial dominance of rugged masculine heroes at the box office and with the western world in the midst of the women's rights movement, BBC's Three Men can function as a welcome critique of patriarchal authority, due to its very lack of it. With all of these factors, in relation to mainstream cinematic conventions, BBC's Three Men in a Boat makes for an effective, if perhaps inadvertent, anti-action, heroically charged, goal-oriented film - a feat achieved by presenting a non-heroic British masculinity.

Visually, BBC's adaptation counters the big-budget style of Bond. For instance, the opening of BBC's Three Men in a Boat conjures the look of a documentary film (where cheaper film stock is used, in comparison to mainstream Hollywood productions or Bond films). The telefilm docudrama visual style is fitting because of the original reputation of Jerome's piece, a work that is noted for its ability to straddle the non-fictional (a boating journey) with the fictional (its caricature of characters and events). While the characterisations in Jerome's original are exaggerations, the characterisations are identifiable - one of the keys to the enduring charm of the work and an important balance that is sustained by BBC's 1975 adaptation. BBC's Three Men in a Boat does not lose that trait of comical truthfulness associated with Jerome's original, due, in part, to the telefilm's documentary look and slower pacing compared to action films. The location sequences (with their natural lighting) come across as authentic, or, certainly, not as polished as a Hollywood or James Bond action film would be. BBC's Three Men also holds onto the authentic charm of Jerome's original through Tim Curry's (as J.) voice-over, which directly states that the film "forms a record of events that really happened" - reinforcing the docudrama tone. BBC's film, like Jerome's original, is not objective, documentary truth (if there ever is such a thing). Nevertheless, the film's contrast with depictions of masculinity (from Hollywood) or of Britain's most famous ambassador of manliness, James Bond, comes across as rather revealing. Like Jerome's original can be viewed as an effective (and refreshing) counterbalance to colonial propaganda regarding white male masculinity, BBC's Three Men is a comic humbling for perhaps even a greater number of media hyper-masculinities.

Perhaps the most recognisable icon of heroic British masculinity in cinema is James Bond. In his current incarnation, with Daniel Craig's chiselled physique and portrayal of intellectual acumen (in Casino Royale, for instance), James Bond comes across as a genetic hybrid of two other British literary and media icons, Tarzan and Sherlock Holmes. Although Bond is not a seafarer in the traditional sense, he, nonetheless, is a global adventurer with an ability to wield a 
wide variety of technologies and vehicles. In "The Masculinity of James Bond", Hoxha (2011: 193) says "The Bond character's take-charge playboy mentality exudes charm, sophistication, vigor, and wit while living a life of elegance, drama, and danger". While the colonising undertone of Crusoe is abandoned (comparably), there is still a high degree of the exotic in Bond, whose travels bring him to the bedside of beauties from the world over. In other words, Bond brings the seafaring, British adventurer into the twentieth and twenty-first centuries. Needless to say, Bond is an ideal embodiment of confident cognisant agency that often characterises the masculine heroic in popular culture. Although BBC's Three Men is not a direct parody of the spy thriller, the film does undermine the heroic male type established by Bond movies.

BBC's Three Men appears in a time when Bond is firmly established as a heroic icon and Hollywood is populated with several gritty, violent action heroes. Like Bond, popular film heroes of the 1970s are also highly capable figures. By the 1970s, Bond has gone through two major incarnations, with Connery and then Moore at the helm. While Barry Nelson played Bond on the American Climax! Television series and even though George Lazenby took on the role in On Her Majesty's Secret Service, in the 1970s, Connery and Moore hold the honour of having a more enduring impact on the role and longevity, in terms of their number of incarnations and identification with Fleming's secret agent. Importantly, by the 1970s, Bond is clearly established as an international icon of heroic masculinity, British and beyond. Even though Moore brings some humour to the role, the humour does not undermine Bond's competency, as, for instance, Peter Sellers undermines the heroic detective in the Pink Panther series throughout the late 1960s and early 1970s. Alongside the gentlemanly danger embodied by Bond, other, grittier, popular male heroes also emerge in popular cinema - figures that exist as media contrasts to BBC's comical variation offered by Three Men in a Boat. In American cinema, the gangster and the Film Noir detective are already established figures, by the time the rough masculinity of the seventies' tough guy hits the mainstream through the aggressive attitudes of Clint Eastwood in Dirty Harry (1971), Gene Hackman in The French Connection (1971), and Charles Bronson in Death Wish (1974). To the mix, also in 1971, there is the Blaxploitation film icon, Richard Roundtree in Shaft. Figures such as these were not only highly capable figures, but also rather intimidating ones, who displayed a rather direct and ruthless violence. Eastwood, Hackman, Bronson, and Roundtree play characters who exhibit unapologetic violence and brutal flair. Compared even to the polish of Bond, Eastwood and others offer a violent intensification of the heroic male ideal. Certainly, with their high pain threshold and drinking ability, one would not find James Bond or Dirty Harry fretting over whether his liver was out of order - as the three men do. In contrast to the typical male hero, like Bond, who refuses to succumb to physical pain and is not only calm but ultra-cool (even witty) under life and death pressures, BBC's three men, although seemingly healthy, insist on expressing pain and distress when there is absolutely no viable threat to their lives, health, or well-being. Within the context of Bond and Hollywood tough guys, which establishes popular media's masculine norm of hyperbolic toughness, BBC's Three Men serves as a comical deflation of such a norm.

Characterisation is central to this challenge of gender norms. If the patriarchal ideal displays confident cognisant agency, then the comical counterpart subverts such qualities. In the very opening of the telefilm, the three main characters begin by admitting to bouts of giddiness, a lack of awareness, and a disinclination to work. As opposed to an active, visual conflict to display their prowess (as would be typical for an action film), Jerome, George, and Harris participate in a relatively sedentary and verbal competition of complaints. The emotional relation with the hero is 
noteworthy, for even "Robinson Crusoe has a consistent sense of himself as a man who is condemned from birth, as if by a fatal degree, to pursue a life of unexampled deprivation and misery" (Erickson 1982: 136). However, this feeling prompts Crusoe into action; in contrast, the three men embrace feelings of victimhood and conjure excuses. Cinematic action heroes can be brooding as well, but their penchant for violent agency propels them towards success by the narrative's end. Physical action cures the brooding hero (or, at least, temporarily soothes... until the sequel). In contrast, BBC's Jerome, George, and Harris are less physical and more pseudointellectual. Importantly, although they sound similar to Bond or Sherlock Holmes, the three men do not show precision thinking. Amusingly, they remain competitive, but their contest is one of perceived or feigned complaints. Instead of actually enduring genuine hardship, from the outset, they narrate hardship, and, in the process, hint at the way identity formation works: through the narratives a people tells themselves. On a cultural scale, narratives about masculinity are ones that discourage complaint - Bond shrugs off actual bullet wounds. BBC's Three Men questions that popular cultural narrative by displaying a lack of action and by offering a counter narrative of imagined hardship and pain. The delusion evident in their narratives is humorous (for they are not actually ill, physically), but also revealing, in the grand cultural sense that the narrativisation being mocked, narratives of heroic prowess, may be equally delusional for an entire community or gender.

If real men do not complain, then from the outset, it is clear that these three are no masculine ideal. Their neuroses stand in stark contrast to the wounded, but uncomplaining hero of legend. Visually, in the opening sequences, the lack of Jerome, George, and Harris is emphasised through both the mise-en-scene and the editing. The staging emphasises an atmosphere of rest, visually exemplified by the way the characters lean back in their chairs, puff on cigars, and discuss imagined maladies. An early visual joke concerns the delivery of dinner, when a (hardworking) female servant signals the arrival of dinner. George and Harris sit around the table, while Jerome inspects a dish. With a quick cut, the telefilm presents a series of empty plates, signalling the end of dinner. This sequence serves as a visual set-up to the lounging image of our key figures and the punch line, "What we need is a rest". As opposed to a male-centred action narrative which establishes the problem and promises a quest of action, within the first two to three minutes, the telefilm effectively establishes the slothful nature of Jerome, George, and William Samuel Harris. Unlike an action film, where the hero's journey is punctuated by daring stunt sequences, this sluggishness is reinforced throughout the telefilm via the frequent stops along the journey.

\section{A non-triple threat: Three Men, three layers}

At this moment, it is useful to emphasise this paper's perspective on the triple layers in the BBC film. On the first layer, in terms of the long-standing value of Jerome's Three Men, its subversion of the myth of the British seafarer is central; related to this, there is the subversion of the hypermasculine hero (of British and many different patriarchal cultures) evident in BBC's Three Men. Arguably, because of such comic subversion, Three Men has become a text of recurrent adaptation. Even more so, the ensemble comedy team recurs, with three (or more) men showing up in different situations. The telefilm's depiction of the trio's frequent stops is observational humour, one that is based upon the way the journey unfolded during the late nineteenth century. 
Simultaneously though, when contrasted with the episodic adventures of the mythic seafarer, like Odysseus, the frequent stops take on a deeper comical critique. The seas are a powerful force in The Odyssey, and the stops are impediments to the protagonist's goal to return home. In contrast, for the three men, the goal of their journey is not necessarily completing the trip; the frequent delays are the point - one that underscores their sluggish, leisurely approach to life. The satiric implication is that masculinity (colonial or contemporary) is marked by a life of leisure, not one of hard work or enduring hardship.

On the second layer, in terms of its observational humour, the original text and the BBC telefilm lend comic insight into human character, especially in terms of the caricatures of individuals and lifestyle in the late nineteenth century. In relation to the hyperbole frequent in heroic adventure fiction of the era, Three Men is refreshing for its comic candidness concerning the Victorian era. Unlike the exotic adventures of Kipling, for instance, Jerome's Three Men turns the narrative lens on England itself. For instance, the opening refers to liver pills, a medicinal treatment that has long since gone out of favour. Jerome's references to liver pills, typhoid fever, or housemaid's knee are comical observations that serve to caricature a particular time period and, thus, such specific cultural and temporal references may be lost on modern readers. More centrally, the entire enterprise of boating trips along the Thames is no longer an identifiable weekend event. Jerome's entire novel serves as a comical observation of a form of leisure once enjoyed by a class in England's past. The stops made in the novel and the particular details of the trip are not references that the average, contemporary reader may recognise. Much of the humour of Jerome's original stems from a special caricature of and comical observations of the time of the work. For instance, people no longer go to the British Museum to read up on treatments for hay fever, pick up The Referee for sports news, snack on Captain's biscuits, or fill their big pipes with tobacco. Nevertheless, these specific references form much of the observational humour of the piece; moreover, the particular references provide a revealing glimpse into the life of a particular class during the latter part of the nineteenth century. To a certain degree, the BBC adaptation preserves some of this observational caricature, through the period setting, the fashion, and the type of boats depicted. However, unlike the original, the BBC version is more of a broad glimpse into England's Victorian past. The success of the 1975 telefilm adaptation perhaps reveals the willingness of the British to laugh at their historical selves. Jerome's novel is distinguished by a tone that uses comical observation in an otherwise realistic setting and circumstance. Thereby, it serves as a meeting point of sociological literary realism and comical observation where the humour arises from character and the witty observations of the narrative voice. Similarly, the BBC telefilm functions as a historical fiction that is also comical. As opposed to being a parody of the historical or period film genre, BBC's Three Men preserves the original novel's caricature of Victorian life, and thus, is rooted in observational humour of a time past, when boat trips and camping defined leisure.

The work's international life hints at the possibility that even those from other cultures identify or identify with the very human foibles - on seeing parts of themselves in the behaviour of the three British men in a boat. Hence, on a related, but third layer, the original and the telefilm are more than a caricature of Victorian life. With caricature, the British or non-British reader/spectator can laugh at the three men. However, by allowing readers and spectators to see themselves in the behaviour of the three men, the texts (Jerome's original and the BBC adaptation) make the humour more human - readers and spectators are not laughing at, but 
laughing with. In other words, Three Men is amusing for its literary subversion, comic caricature and observation, and relatable characterization.

\section{Identity baggage: Lacking confidence and gender role reversal}

Historically, when Jerome's original appears, colonialism exists and western feminism is in its first wave. Within such a political climate, Jerome's central male figures can be taken to be politically significant, for the three men exhibit vulnerabilities not normally associated with literary male protagonists during the Imperial Age. Due to the work's self-professed truthfulness, the comical depictions become even more socially relevant, helping chip away at the imbalanced colonial celebrations of white male prowess. By the 1970s, when BBC's Three Men in a Boat appears, the world has entered the postcolonial era and the feminist movement is well into its second wave, handling concerns with gender inequality in the workforce and cultural doublestandards. Within such a political climate, paralleling the original, BBC's version is also politically significant. In the cultural context of the hyper-masculinity of Dirty Harry on the one hand, and the women's liberation movement on the other hand, BBC's telefilm of three incompetent, neurotic, and lazy white males holds a potential political charge. While the telefilm, like the original, is often taken to be a light diversion and can be enjoyed as such, due to its historical timing, the telefilm can also be treated as a notable challenge to popular conceptualisations of gender norms.

Along with being delusional about their health and sluggish on their journey, the three men also seem to lack an ability to pack for a trip in an efficient manner. This comical act reveals their lack of confidence in themselves. Without the confidence of Dirty Harry or Bond, BBC's three men need far too many things - they are far from self-reliant. Bond takes only essential, highly effective weapons, while more rugged men, such as Crusoe or Dirty Harry, are so manly that they survive with merely any supplies. The BBC's choice to include this sequence reveals the contradictory feelings about masculinity as a dominator of nature and as a civilising cultural force. In the late nineteenth and early twentieth centuries, there is the masculine "desire to strip off civilization with one's clothes and to experience primitive life firsthand in contact with nature" (Kassan 2001: 190). Yet, simultaneously, there is the Imperial assertion of a strict, racebased divide between the civilised and uncivilised. The Victorian contradiction between the rugged male and the civilised gentleman also ties into notions of gender, for clearly one (the rugged) is more masculine than the other, and being rugged alone is not enough, for being deemed civilised brings hierarchal status. The preferred merger of the rugged/civilised indicates the Victorian crisis over masculinity and notions of the masculine and feminine as they apply to the world of business, the basis of power for the Imperial male. Luxury was perceived to be altering a society of military might and conquest (more masculine traits) to a more effeminate society of trade and comfort (Berry 1994; Sekora 1977). Kimmel (2005: 139) suggests that the concern over the feminisation of men dates back to the late seventeenth and early eighteenth century, due to concerns over urbanisation: "the city feminises men, removing them from the land (the source of productive labour, and hence diligence and masculine discipline) and exposing these rough-hewn rural men to the effete life of the fop". The city, a site of technological and economic progress, of civilisation-building, is also perceived as a threat. Hence, the contradiction between the narrative of rugged self-reliance required by the enterprising seafarer and narrative 
of the civilised superiority used as a justification for colonial (or class or gender) rule is not lost on either heroes or their comic counterparts. While heroes attempt to reconcile this contradiction, the comic counterpart exposes it as a deep, irreconcilable fracture in masculine identity discourse.

Along with the masculine lack of self-reliance versus the fear of excess comfort depicted by the numerous bags sequence, to the contemporary audience, the inclusion of numerous bags can also serve as a gender reversal; as opposed to the comic stereotype of women needlessly overpacking, in Three Men, the males take on that honour. The sheer number of bags extends their paranoia over health into their clear discomfort with travel. Gender reversal occurs later on the river as well, when the stereotypical topic of womanly interest, fashion, is the theme for the three. Back in the train station, as the excessive luggage joke completes, the camera moves to other males, indicating that the incompetence depicted by our three main characters can be extended to other men, in this case, men in uniform. In response to inquiries about the time of the train, no uniformed train official can offer any clarity. Even the train engineer is uncertain, until a bribe is paid. On one level, this can be taken to be a comical depiction of the function of bribery in everyday British life of the time; on another level, the bribery can be said to depict how masculine power is linked to finances. As opposed to the masculine hero's abilities and skill providing agency, one's abilities and hard work are not necessarily rewarded. In actual life, agency is linked to financial power. Indeed, the entire boat trip is dependent upon the financial resources and leisure time of Jerome, George, and Harris. Unlike the rugged, lone adventurer living off the land, the three men are spoiled males who have considerable trouble with the natural world and even their own psyche despite their resources.

\section{Lost: Non-cognizance in leadership}

A parody of the superhuman orientation and problem-solving skills of the Bond type and his Hollywood counterparts, the BBC telefilm provides a flashback to Hampton Court maze. Instead of easily working through the maze, Harris is stuck in the maze for several hours. Harris takes on the role of the capable leader, rounding up other visitors and urging them to follow him. Upon realising he is lost, Harris sustains the façade of confidence, while leading the group. His false leadership continues until a minor mutiny. The contrast between desired heroic image and actual human practice is perhaps best symbolised in the photograph sequence.

Before discussing the photograph sequence, however, it is important to note how the nineteenth century British Empire was a time of photography. When photographs emerge, they are a curiosity. As Novak (2011: 65-87) demonstrates, reactions to Victorian era photography were not uniform, and the photographic image was not taken by all to represent reality faithfully. Nevertheless, one view was that photographs constitute a great documentary power, in the sense that actual life is being captured. As it relates to ideas about the rational, objective male, this belief in the power of the photograph cannot be understated, for while the photograph has the status of capturing time and space as it is, the photograph does not exist in a narrative vacuum. When photographs take on increasing value as indicators of objectivity, their usage can uphold or undermine circulating discourse about identity. By the late-nineteenth and early twentieth century, photographs of the powerful white male body reinforce the narrative of racial superiority. For instance, Eugene Sandow "became an icon of the hypermasculine who with his extraordinary muscular development literally embodied characteristics that many men and women believed 
were threatened by modern life" (Kassan 2001: 29). While Sandow's popularity peaks in the decades after the first edition of Jerome's Three Men, the Victorian concern over the narrative of the daring, enterprising male versus the narrative of the softer, urban male was already present. As the muscular body relates to twentieth century cinema, by the 1970s, mainstream heroes are not necessarily hyper-muscular (as they would become in the 1980s with stars like Stallone and Schwarzenegger), but the 1970s Hollywood tough guy does exhibit a raw, physical strength and intimidating capability. To this day, the stern face of the hero dominates Hollywood posters; there is no Bond poster with Bond as fear-driven secret agent.

Moving into the BBC film's photograph sequence directly, the view notices the three men posing for a photograph. As this occurs, Jerome states that he is aiming for an image of "agility and strength," but when the photo is taken, the three topple, leading to a rather non-heroic portrait. This visual moment is especially significant because, on one level, it represents the underlying comic contrast, the delusional self-image of Imperial British masculine and racial superiority in relation to a frank depiction of relatively average trinity of British males. On another level, the un-heroic photograph caricatures Victorian concerns over masculinity, due to the shift from the era of seafaring expansion to the era of leisurely cruises. On a third level, the laughter is not one of complete mockery though, because the characters are likeable and the situation is both plausible and identifiable; audience members can easily imagine themselves in a similar situation, leading to a blurry photograph.

The frank documentary tone of Jerome's original text and related docudrama style of the $\mathrm{BBC}$ telefilm reinforce the comic critique, as though the film is saying that the British are lying to themselves, if they wholly believe in Imperial propaganda, especially the inequality of the races. After the photograph sequence, there is a self-aware moment that lends credence to the layers involved in the BBC adaptation. George and Harris are rowing, blaming Jerome for the illfated photograph, but as the voice-over begins its retort, George and Harris protest, "Not now, J!" Typically, the narrative voice-over does not converse with the characters, and the characters certainly do not have narrative control over the invisible, off-screen voice. However, in this case, by subverting Jerome's voice-over, the characters are also subverting the idea of narration, pointing out how the narration of documentaries and other styles (Film Noir, for instance) are far from objective. With this meta-moment juxtaposed with the preceding photographic moment, the telefilm highlights the Imperial British narrative of the masculine self in contrast with other possible variations of male identity - in this case, the film itself.

\section{Fumbling along: Trouble with agency}

The contrast between narrative voice-over and character also makes for an appropriate comic subversion of the Film Noir voice-over. With his voicing of hardship, Jerome relates to a Film Noir narrator who is often also a central character - unlike the voice-over in a documentary. While the Film Noir or private investigator protagonist may have to deal with actual life and death situations, Jerome must deal with the tragedy of not having a condiment, mustard, available for their picnic. Later, Film Noir imagery is evident in the scene of night-time search. Unlike the dramatic Film Noir match, which is lit with precision and lasts an opportune moment to provide a dramatic visual contrast between light and dark and a moment of suspense (until the flame disappears), Jerome and George repeatedly strike matches for brief moments of fleeting light, 
while shouting, "Harris!". When they finally meet up, an exhausted Harris claims his fatigue is due to a battle with swans. The swan battle is not shown, but earlier in the telefilm, there is a key moment of slapstick that occurs with the tin pineapple sequence that requires discussion. While the action hero can do wonders with the minimal of devices against the most dangerous of foes, George, Harris, and Jerome are bested by an inanimate can of pineapple.

Certainly, an action film would not be complete without a chase - the same requirement exists for a comic inaction film. When the dog, Montmorency, runs off, the three men engage in a chase, paralleling the earlier flashback (in the Hampton Court maze), in the sense that the three men are now not lost in a maze, but in the streets of Marlow, bested by their dog. Like the Hampton Court maze in the earlier sequence, in the streets of Marlow, brick walls serve as their new maze. In this way, the maze serves as a recurrent visual motif in the film; however, while the heroic male adventurer can find his way through the exotic maze of a jungle or navigate dangerous voyages, these three men are unable to direct themselves within a garden maze, a known urban space, or down the river Thames. As opposed to being the heroic male who dominates nature and animals, these men could be said to be dominated by nature and animals. Reinforcing their lack of heroism, during their pursuit of their dog in the brick maze of Marlow, there is a notable reference to Shelley. Specifically, the voice-over references Shelley's dedication to his wife, Mary, from "The Revolt of Islam". The lines recited in the film include "So now my summer-task is ended, Mary/ And I return to thee, mine own heart's home". The passionate tone of Shelley's poetry is at odds with the ridiculousness of three grown men, unable to open a tin of pineapple or keep up with their small dog. Apparently, the chase for the dog is quickly ended when the three men crash into Shelley, knocking Shelley and one another over. Not to worry though, as Shelley appears later, musing in a boat, safe from any injury. The comic imagery here is especially appropriate, for while the telefilm is mocking the British seafarer, it is also undermining the legacy of, or crashing into, British Romantic heroism. With his wild, antiauthoritarian, and rebellious personae, the British Romantic hero is a glaring contrast to the below-average, uninspiring abilities of George, Harris, and Jerome.

\section{Becoming human: The relatable humanity of the Three Men}

Nevertheless, George, Harris, and Jerome remain identifiable figures, for their humanness. Despite their heroic subversion and caricature of the needlessly neurotic, the three men are successfully relatable by the end of the BBC film. In part, this is due to the acting abilities of Tim Curry, Michael Palin, and Stephen Moore. While there are moments where their comedy is overthe-top, there are also moments where their comedy communicates realism. Also, the relatability of the three principal characters is due to the direct voice of Jerome, the voice-over of the telefilm. The audience gets to know the three men through their adventures, and despite their inabilities - or even because of them - the three men are still rather likeable. When the three discuss something as simple as boiling river water for tea, their discussion is identifiable, to this day, for anyone who has had to go camping or boil water to drink. Quite possibly, as audiences become more accustomed to urban life and the digital age, audiences today may even identify more (than audiences in 1975) with the lack of practical skills and life of leisure revealed by BBC's three men. 
Moving them beyond comic types (as subversions of heroic masculinity) or comic caricature (as delusional adult males), the BBC film allows for sensitive moments. As George and Harris are about to drink the tea, they notice there is a dead sheep in the river; however, their reactions are not played for laughs. Rather, they react in a plausible manner. George and Harris dump their tea into the river, while Jerome, having drunk some of his tea, worries over whether he has typhoid. Here as well, initially, Jerome's concern is grounded in the reality of the situation. The spectator can honestly worry for Jerome, so his line about "typhoid" functions on three levels: as heroic subversion (a Bond type would not worry, but Jerome does), as caricature (anxiety over typhoid is true to Jerome's character), and as relatable (upon witnessing a dead body, the average viewer may also lose the desire for a sip of tea). With moments such as these, along with being caricatures in exaggerated situations (attempts to open the tin can of pineapple), and along with being a comic subversion of the heroic seafarer, the three men are more than simply a comic device or a comic type - they are also recognisable.

One of the most recognisable elements stems from the way identity seems to work. Jerome's concern over typhoid slips into a flashback, where the concern then becomes exaggerated and more comical. The flashback offers a glimpse into Jerome's general paranoia over his health. While a male hero like Theodore Roosevelt famously could give a speech after being wounded by a bullet, a mere thought of illness can cause Jerome to convince himself of illness. This paranoia is identifiable to a degree as well, but the flashback deflates any genuine threat of typhoid, due to the melodramatic acting and music. In other words, the genuine concern evoked by the dead sheep in the river and the concern over tainted tea shifts back into the comic distance provided by parody. During this moment, the telefilm may even push towards satire. Jerome looks into a mirror, inspecting his eyes; this works as an effective moment of visual symbolism, for the film can also be taken as a comic reflection of the way heroic masculinity or national image works. The hero ventures forth on daring quest, and the Imperialist patriarch builds himself up through hubris, fuelling the belief in the right to civilise the world. In contrast, the hero's comical opposite, Jerome, quarantines himself through paranoia. In the flashback, the visuals (of a robed Jerome seated in a rocker, studying the medical text, and claiming to go through things systematically) parody Sherlock Holmes. After the doctor's visit and a trip to the pharmacy, the flashback and joke concludes, moving back to the present action with sage and rather reasonable advice, "Don't fill your head up with things you don't understand". In terms of how the advice relates to identity formation, in a sense, identity works by the imaginings of a people.

\section{Identity and humbling self-reflection}

For Benedict Anderson (1982: 6), a nation "is imagined because the members of even the smallest nations will never know most of their fellow-members, meet them, or even hear of them, yet in the minds of each lives the image of their communion". If, as Benedict Anderson insists, people are a part of imagined communities, then national identity is forged by filling our heads up with things we do not quite understand, especially those we imagine as The Other. Technically though, the community's sense of unity is based upon a distorted or biased sense of both those deemed insiders and outsiders. Identity is not determined by blood or geography, but by what one imagines to be his or her community. Identity is assumed to be imagined because people can 
switch communities rather easily. By the time the three men shift from rowing their own boat to becoming passengers on a steam-powered boat, the audience can glimpse the three's shift in identity. Earlier, the three men imagine themselves to be rowers, scoffing at boats powered by steam; moreover, they bond by critiquing others on the river, both young and old. Demonstrating male self-definition via binary contrasts, the three men even question the role of women on the river, while admiring their appearance. In such moments, the three men are building an imagined community, a sense that they are viable rowers and men of the right age. They define themselves via negativa, by what they are not: old, young, or women. Their judgements of others are humorous, but based on stereotype; perhaps more importantly, their judgement of themselves, as manly rowers, is delusional. Nevertheless, the behaviour of the three men parallels the behaviour of people around the world, of any community that imagines its own sense of civilised unity in contrast to those deemed outsiders, and thus lesser. As men, their identity rests upon patriarchal assumptions about themselves, in contrast to simplified notions of the opposite sex. The community of these three men has been built by their own shared notions of who is an insider and who is an outsider, as illustrated by the way the three men berate a boat of sleeping rowers (rowers that mirror the way the three were behaving not too long ago). The rowers the three men berate get in the way of their new, more comfortable, steam-powered boat; allegiances to an imagined community can shift, depending upon whether one is in a rowing boat or a steampowered boat.

As the trip progresses and the three men return to their rowing, the humour continues to function in a layered manner. The three men become more frustrated with one another, reinforcing the danger of building identity via opposition. Like an actual community, the perceived similarity of any one group is based upon imagined similarities. No matter how superficially similar a group may be (white, male, British), once a member gets to know another member a bit more, he may be surprised to learn that they do not share the same perspective on things. Later on in the telefilm, the community of three men fractures a bit, and their turmoil is symbolised by the rain. As it rains, the three quarrel with one another, restless to return home. Harris remains motivated by food, imagining that he will return to the comfort of home and enjoy a lavish dinner, although he is uncertain of what dishes to select. As opposed to enjoying the fantasy offered by Harris, the more practical George takes up the oars and rows vigorously. Jerome functions as a mediator of sorts, claiming they all agreed to work together to complete the trip - Jerome says this, despite his own reluctance to row. Despite their similarity as a community of rowers, like any community, the three also have distinct perspectives, evidenced by how they relate to one another in the rain sequence. Worried about the threat of death, George rows hard. Harris may also be worried, but, due to his laughter, he is either unaware of the potential seriousness of their predicament, or he is simply not as concerned. Jerome listens to both, speechless, until he notices a dead body in the river. Here, the tone switches again, and becomes more sober. The lady lies in the river, like Ophelia from Hamlet; the literary allusion becomes more obvious when Jerome narrates her story of love and suicide. The poignancy of the death brings greater weight to the telefilm, enhancing its pacing and making the threat of the river more palpable - and hinting at the threat of neuroses left untreated. For a brief while, George's paranoia (over their predicament of being stuck in the rain two days from the end of the river trip) seems authentic. Hence, by the end, they decide to abandon their ship and the trip, in favour of an easier route home, via train. The potential fracturing of their little community of three is healed by the commonality of comfort - a good unifier of many Imperialistic communities. In terms of 
gender, their choice undermines the more masculine choice of enduring until the end and conquering the river, and can be taken as comical reinforcement of their parody of manhood.

National and gender identities aside, because the characters are in the miserable situation of being stuck in the rain, their decision to abandon the river (and perhaps even the myth of the civilised seafarer) is one that is comically identifiable. That is, these characters are making a plausible choice that is amusing because some members of the audience, from any community, may do the same, if they were in the same situation as these three men. Even though the choice of the three men does not live up to the heroic ideal, their choice is charming for its candour, or comical honesty. Fittingly, the film ends in a style that is associated with autobiographical or docudrama honesty, with the narrator revealing the actual individuals upon which Harris and George are based. In addition, the narrator tells about their futures, like George Lucas famously communicates via titles at the end of American Graffiti. As opposed to the opening, which undermines the narrative authority of the voice-over by pairing Jerome's voice with the opening scene of neurotic complaints, the style of the ending actually lends authority to Jerome's narrative voice-over, closing with Jerome leaving his desk, upon which the written text rests. By the end, Jerome comes across like a trustworthy voice of traditional documentaries and docudramas. Looking at the different tone of the opening and the closing of the BBC telefilm reveals how the film's comedy is one of differing, but interactive, and simultaneous, layers.

\section{Conclusion: Triple threat}

Attempting to discover why a work like Three Men in a Boat endures is a task of speculation. Because of its theoretical nature, there is always room for alternate possibilities. The hypothesis here is that the work will not go away soon because it is a key text in the British and popular culture's comic counterbalance to the masculine hero, a timely predecessor of two parallel streams: one stream consists of heroes, like Sherlock Holmes, Tarzan, and Bond; another stream consists of comic subversions, like Keaton, Chaplin, and Sellers. Even though the particular Victorian references (in the novel, especially) become increasingly inaccessible as time moves forward, so long as England, Hollywood, or any part of the world continues to celebrate the superhero, Three Men (and especially updated, cinematic adaptations of it) should have a place. As opposed to showcasing their confident cognisant agency, BBC's three men expose their neurotic, delusional incompetence; in doing so, the film confesses the tendency towards hyperbole when it comes to heroes. Despite this grand, underlying subversion, on another, perhaps more obvious level, the work offers a playful set of caricatures. Taking the spectator back in time, to the late nineteenth century, the film indulges in the idiosyncrasies of the Victorian male and Victorian culture. With its rootedness in the stereotypical stuffiness of the Victorian era, the text has several available targets in the three men, those they encounter, and the lives they lead. However, neither the novel nor the BBC film slips into a complete caricature, or a comic distance where the characters turn into types. Rather, at its final level, BBC's Three Men also reveals a sense of humanity, an authenticity of human experience and character. Jerome, as the narrator, through his self-critique (of masculinity, Victorian culture, and himself) reveals a certain maturity of character, a willingness to question the Imperial ideal and mock assumptions about masculinity and self. By the end of the 1975 BBC film, it is clear that there are more than three men involved in the journey, for the spectator is also along for the row - and is better for it. 


\section{References}

Anderson, B. (1991 [1982]). Imagined Communities: Reflections on the Origin and Spread of Nationalism. New York: Verso.

Berry, C. (1994). The Idea of Luxury: A Conceptual and Historical Investigation. New York: Cambridge University Press.

Defoe, D. (1975 [1719]). Robinson Crusoe. Edited by Shinagel, M. New York: W. W. Norton and Company.

Erickson, R. A. (1995 [1982]). 'Starting over with Robinson Crusoe', in Bloom, H. (ed.), Daniel Defoe's Robinson Crusoe, New York: Chelsea House Publishers, pp. 51-73.

Frears, S. (1975). Three Men in a Boat. Great Britain: British Broadcasting Corporation.

Hoxha, T. M. (2011). 'The masculinity of James Bond: Sexism, misogyny, racism, and the female character', in Weiner, R., Lynn Whitfield, B. \& Becker, J. (eds), James Bond in World and Popular Culture: The Films are Not Enough, Newcastle upon Tyne: Cambridge Scholars Publishing. pp. 191-203.

Hunter, J. P. (1966). The Reluctant Pilgrim: Defoe's Emblematic Method and Quest for Form in Robinson Crusoe. Baltimore: John Hopkins University Press.

Jerome, J. (1982 [1889]). Three Men in a Boat (To Say Nothing of the Dog). Annotated and introduced by Matthew, C. \& Green, B. London: Pavillion Books.

Kasson, J. F. (2001). Houdini, Tarzan, and the Perfect Man: The White Male Body and the Challenge of Modernity in America. New York: Hill and Wang.

Kimmel, M. S. (2005). The History of Men: Essays in the History of American and British Masculinities. Albany: State University of New York Press.

Mansfield, H.C. (2006). Manliness. New Haven: Yale University Press.

Novak, D. A. (2011). 'A literature of its own: Time, space, and narrative mediations in Victorian photography', in Colligan, C. \& Linley, M. (eds), Media, Technology, and Literature in the Nineteenth Century: Image, Sound, Touch, Farnham, Surrey, England \& Burlington, VT, USA: Ashgate Publishing, pp. 65-90.

Rogers, P. (1979). Robinson Crusoe. London: George Allen and Unwin.

Scheick, W. J. (2007). 'Going to find Stanley: Imperial narratives, shilling shockers, and Three Men in a Boat'. English Literature in Transition: 1880-1920 50 (4), pp. 403-414.

Sekora, J. (1977). Luxury: The Concept in Western Thought, Eden to Smollett. Baltimore: John Hopkins University Press.

Stepan, N. (1982). The Idea of Race in Science: Great Britain, 1800-1960. London: Macmillan Press.

Watson, H. F. (1966 [1931]). The Sailor in English Fiction and Drama: 1500-1800. New York: AMS Press.

Zackel, F. (2000). 'Robinson Crusoe and the ethnic sidekick'. Bright Lights Film Journal 30. http://www.brightlightsfilm.com/30/crusoe1.html.

\section{Films}


Abrams, J. J. (2009). Star Trek. United States: Spyglass Entertainment and Bad Robot Productions.

Annakin, K. (1956). Three Men in a Boat. Great Britain: Romulus Films

Campbell, M. (2006). Casino Royale. Great Britain: Eon Productions.

Cutts, G. (1933). Three Men in a Boat. Great Britain: Associated Talking Pictures.

Edwards, B. (1964). Pink Panther. United States: Mirisch Company.

Friedkin, W. (1971). French Connection. United States: $20^{\text {th }}$ Century Fox.

Garfield, B. (1974). Death Wish. United States: Paramount Pictures.

Hunt, P. (1969). On Her Majesty's Secret Service, Great Britain: Eon Productions.

Landis, J. (1986). Three Amigos!. United States: Home Box Office Films.

Lucas, G. (1973). American Graffiti. United States: American Zoetrop and Lucasfilm.

Nimoy, L. (1987). Three Men and a Baby. United States: Walt Disney Studios.

Parks, G. (1971). Shaft. United States: Metro-Goldwyn-Mayer.

Phillips, T. (2009). The Hangover. United States: Legendary Pictures.

Roach, J. (1997). Austin Powers: International Man of Mystery. United States: New Line Cinema.

Sanderson, C. (1920). Three Men in a Boat. Great Britain: Artistic Films.

Shadyac, T. (1994). Ace Ventura: Pet Detective. United States: Warner Bros.

Siegel, D. (1971). Dirty Harry. United States: Malpaso Productions.

Zemeckis, R. (2000). Castaway. United States: Twentieth Century Fox.

\section{Literature}

Beowulf: A Verse Translation. (2003 [10 $\left.\left.{ }^{\text {th }} \mathrm{C}\right]\right)$. Translated by Alexander, M. London: Penguin Books.

Burroughs, E. R. (2008 [1914]). Tarzan of the Apes. Project Gutenberg. http://www.gutenberg.org/ebooks/78.

Doyle, A. C. (2011 [1892]). The Adventures of Sherlock Holmes. Project Gutenberg. http://www.gutenberg.org/ebooks/1661.

Haggard, H. R. (2005 [1885]). King Solomon's Mines. Project Gutenberg. http://www.gutenberg.org/ebooks/2166.

Homer. (2003 [VIII BC]). The Iliad. Translated by Fagles, R. \& Knox, B. New York: Penguin Books.

Homer. (1999 [VIII BC]). The Odyssey. Translated by Palmer, G. H. New York: Dover Publications.

Jerome, J. (2006 [1914]). Three Men on the Bummel. Project Gutenberg. http://www.gutenberg.org/ebooks/2183.

Jerome, J. (1891 [1885]). On the Stage and Off: The Brief Career of a Would-Be Actor, Internet Archive. https://archive.org/details/onstageandoffbri00jeroiala.

Jerome, J. (1993 [1886]). Idle Thoughts of an Idle Fellow. Project Gutenberg. http://www.gutenberg.org/ebooks/849.

Lees, J. A. \& Clutterbuck, W. J. (2011 [1882]), Three in Norway. Project Gutenberg. http://www.gutenberg.org/ebooks/36597.

Roosevelt, T. (1920). An Autobiography. New York: Charles Scribner's Sons. 
Stanley, H. M. (2004 [1872]). How I Found Livingstone: Travels, Adventures, and Discoveries in Central Africa. Project Gutenberg. http://www.gutenberg.org/ebooks/5157.

Stanley, H. M. (2012 [1890]). Through the Dark Continent: Or, the Sources of the Nile, around the Great Lakes of Equatorial Africa and Down the Livingstone River to the Atlantic Ocean. World Digital Library. http://www.wdl.org/en/item/7770/.

Swift, J. (2011 [1726]). Gulliver's Travels. New York: Penguin Books.

Voltaire. (2005 [1762]), Candide, or The Optimist. London: Penguin Books.

\section{Television}

Climax!. (1954-1958). A. Barr, M. Manulis \& B. Windust (Prod.). Columbia Broadcast System, TV Series.

MacGyver. (1985-1992). J. Rich (Prod.). American Broadcasting Company, TV Series.

The Simpsons. (1989-Present). M. Groening \& J. L. Brooks (Prod.). $20^{\text {th }}$ Century Fox Television, TV Series.

South Park. (1997-Present). T. Parker \& M. Stone (Prod.). Comedy Central, TV Series.

Survivor. (2000-2013). M. Burnett (Prod.). Columbia Broadcast System, TV Series. 